\title{
THE ROLE OF EMPLOYEE EMPOWERMENT, TEAMWORK, AND EMPLOYEE TRAINING ON ORGANIZATIONAL COMMITMENT
}

\author{
Restu Purba Riyadi \\ Faculty of Islamic Economics and Business, IAIN Surakarta, Indonesia \\ Restupurbariyadi31@gmail.com \\ Zakky Fahma Auliya \\ Faculty of Islamic Economics and Business, IAIN Surakarta, Indonesia \\ Zakkyfahma@iain-surakarta.ac.id
}

\begin{tabular}{|c|c|}
\hline Article Info & Abstract \\
\hline $\begin{array}{l}\text { Article History } \\
\text { Received: } \\
20 \text { April } 2021\end{array}$ & $\begin{array}{l}\text { This study aims to determine the influence of employee } \\
\text { empowerment, teamwork, and employee training on the } \\
\text { organizational commitment of employees at the Banyumas } \\
\text { Public Works Office. The population used is employees who } \\
\text { work at the Department of Public Works of Banyumas Regency. } \\
\text { The research method used was a quantitative method with a } \\
\text { purposive sampling technique. The data analysis technique } \\
\text { used was multiple linear regression. In this study. The data } \\
\text { source used was primary data employing SPSS 23.0 software. } \\
\text { Data collection methods in this study were questionnaires. The } \\
\text { sample of this study was } 80 \text { respondents. The results of this } \\
\text { study indicate that (1) employee empowerment has a } \\
\text { significant influence on organizational commitment, (2) } \\
\text { teamwork has a significant influence on organizational } \\
\text { commitment, and (3) employee training has a significant } \\
\text { influence on organizational commitment. }\end{array}$ \\
\hline & $\begin{array}{l}\text { Keywords: Employee Empowerment, Teamwork, Employee } \\
\text { Training, Organizational Commitment }\end{array}$ \\
\hline
\end{tabular}

\section{INTRODUCTION}

Employees possess a central role in building the company. The company will be successful with employee whose skills, expertise, and experiences that are in line with the needs of the company. The company is expected to recruit the right people for the right jobs as well as motivate, assess, and provide training for evolving competencies needed. Employee competence will continue to develop in line with changing job demands. In facing non-linear problems, competence is not enough because companies also need employees who do their jobs as well as possible and have a strong organizational commitment (Dessler, 2015). Organizational commitment is considered as one of the important goals for organizations to maintain their existence and survival 
(Hanaysha, 2016). Employees who are committed and loyal are needed by an organization, because employees who are highly committed to the organization will be more productive, harmonious, have high loyalty, and have a higher responsibility for their work (Karim \& Rehman, 2012).

Organizational commitment can be useful for organizations and employees since it can strengthen a sense of belonging, job security, career development, increase compensation, and rewards. The benefits for the organization include increasing the number of employees, lowering turnover rates, pressing training costs, increasing job satisfaction, achieving organizational goals, and improving the quality of products and services (Azeem \& Akhtar, 2014). Employees who have a high commitment to their organization will view performance as something important and make themselves feel responsible for the goals of their organization and thereby voluntary engage themselves with their work by taking their time, willingness, and energy for their work (Albdour \& Altarawneh, 2014). Organizational commitment according to Hanaysha (2016) is a step for the company to develop a mindset in completing the tasks of its employees. There are three aspects to this commitment. They are employee empowerment, teamwork, and employee training.

Employee empowerment is one of the most foremost discussed subjects in human resource management. Empowerment is a process that allows employees to set work goals, make their decisions, and solve problems related to their responsibilities and authorities (Hutagaol, 2014). Empowerment is a process to make people more empowered or more capable to solve their own problems by giving trust and authority to foster responsibility (Mahiri, 2017). Abdullah et al., (2015) argue that empowerment can be seen as a way to encourage individual commitment to the organization. According to Idayanti Nursyamsi (2012), employee empowerment has the most dominant effect on organizational commitment, where companies encourage employees to take advantage of all available facilities and resources. According to Karim \& Rehman (2012), empowerment makes employees realize that their presence is valued in their organization and creates an increase in the level of organizational commitment.

Teamwork is a group of individuals who work together to attain a similar objective. This group of individuals must have clear rules and work mechanisms. Thus, there is coordination and procedures that must be agreed upon by all team members. In addition, teamwork is an activity or process that includes activities to share information about the problems to work together in solving these problems (Masyithah et al., 2018). According to Robbins \& Judge (2015), the characteristics of work include having collective goals, being able to synergize, having individual and shared responsibilities, and having complementary skills for each member. Teamwork is very important to all employees in a company. Teamwork consists of the ability and expertise to obtain and collate information with the support of teammates, to achieve the goals and mission of the organization. 
50 Riyadi, R. P. \& Auliya, Z. F., The Role of Employee Empowerment, Teamwork, and...

Teamwork can be expected to positively affect organizational performance, which in turn will increase employee commitment to the organization (Zincirkiran et al., 2015). Good teamwork is a driver of organizational commitment, work innovation, and ultimately increases employee performance.

Training is defined as a systematic process to assist employees to move forward their knowledge and skills. Training greatly contributes to organizational competitiveness and investment in training can contribute to improving individual and organizational performance (Yusnita \& Fadhil, 2015). The training of skills and knowledge can be considered as the most important investment in human resources made by the organization. Training can also be considered as a way to increase the level of employee satisfaction regarding personal and professional development (Dhar, 2015). Adisaksana et al., (2015) state that job training can align company goals and employee feelings and establish good relationships between supervisors and subordinates. This can affect organizational commitment since the close relationship between superiors and subordinates and the establishment of harmony between individuals and organizations will make employees more loyal and committed to the organization.

Several studies have revealed that employee empowerment influences organizational commitment Hanaysha (2016), Hutagaol (2014), Ismail et al., (2011), Setiawan \& Piartrini (2018). In contrast, different research results found by Karim \& Rehman (2012) saying that employee empowerment does not have a significant influence on organizational commitment. There is a research gap in some of the previous studies mentioned. This research concerns employee empowerment, teamwork, and employee training to form organizational commitment at the Banyumas Regency Public Works Office.

\section{LITERATURE REVIEW AND HYPOTHESIS DEVELOPMENT}

\section{Organizational Commitment}

Building organizational commitment is undoubtedly exceptionally imperative for all organizations as employees are the main source for success. Highly committed employees are characterized by their greater support for the organization to amplify global success. However, to retain employees in any organization, managers must provide a facilitative and pleasant work environment as well as support (Hanaysha, 2016). Employees with organizational commitment have a high belief in the goals and values of the organization and voluntarily obey the orders and goals of the organization. In this case, employees also put a lot of effort into realizing the desired goals and show a commitment to remain in the organization (Zincirkiran et al., 2015). 
Organizational commitment is considered as a mental and emotional reliance for the organization. Committed employees will show their abilities in the organization, participate and engage in the organization, and enjoy membership in the organization (Ghorbanhosseini, 2013). The commitment of employees has different levels, from low to high levels. According to Allen and Meyer (1990) in Khalip (2016), there are three dimensions of organizational commitment identified. They are affective, continuance, and normative.

1. Affective commitment

The affective component relates to the emotional attachment, identification, and involvement of employees in an organization. Affective commitment takes into account three main aspects including the development of psychological affection for an organization, relationship with the organization, and the desire to remain as a member of the organization.

2. Continuance commitment

This commitment is based on the employee's perception of the losses when leaving the organization. Employees with a strong commitment will continue to belong to the organization because they need it.

3. Normative commitment

Normative is employees' feelings about the obligations they must give to the organization and these actions are the right things to do.

Karim \& Rehman (2012) describe employees who are affectively committed, continue to work consistently with great dedication, then there is a continuance commitment that employees will maintain their organizational membership, employees who remain are usually without coercion and in the end, they will stay in their organization.

Organizational commitment can depict the desire of employees to take an interest in accomplishing company objectives. Wulandari (2020) dan Hanaysha (2016) assert that organizational commitment can be measured using some indicators. They are a strong desire to remain as a member, pride to be in the organization, and considering the organization a good place to work. The desire to try hard at work and the feeling of comfort make employees feel motivated to perform better. Acceptance of organizational values refers to the values applied and applicable in the organization are in accordance with the values held by employees. Acceptance of organizational goals is an employee's desire to remain in the organization that makes employees try hard in carrying out their duties so that organizational goals are achieved. They will not leave the organization for ethical reasons and also feel a loss to leave the organization.

\section{Employee Empowerment}

Empowerment is an exertion to allow supervisors trust to subordinates and encourage them to be creative in order to complete their duties as best they can. It is supported by the opinion 
52 Riyadi, R. P. \& Auliya, Z. F., The Role of Employee Empowerment, Teamwork, and...

of Hutagaol (2014) that empowerment is a process that provides opportunities for workers to set goals related to their own work, make decisions, and solve problems within their own scope of responsibility and authority. Empowering employees in the form of excelling in sharing information and increasing intellectual capacity and autonomy while making decisions. Empowerment not only allows freedom of action but also increases responsibility and accountability. Empowerment makes employees realize that their presence is valued in their organization and creates an increase in the level of organizational commitment and job satisfaction, and encourages employees to be creative and innovative (Karim \& Rehman, 2012).

Employee empowerment is a democratic approach where the leader encourages employees to be involved in making decisions related to work (Ismail et al., (2011). Empowerment can increase employee work commitment and feel to change that helps organizational goals. Abdullah et al., (2015), stated that empowerment can be seen as a way to encourage individual commitment to the organization because it increases the fit between work roles and confidence in the individual's ability to do a good job and encourages employees to put more effort into behalf of the organization and participate more in decision making.

Empowerment builds commitment and intelligence. They clarified that employee empowerment has provided benefits to the organization which in turn increased employee commitment to the organization. According to Hanaysha (2016), the indicators in measuring employee empowerment are having confidence about the ability and skills to do the job, having the authority and trust from the manager to make the decisions, and having sufficient opportunities for freedom in doing work

\section{Teamwork}

Teams refer to two or more people who voluntarily work together to attain certain foreordained objectives whereas teamwork is an action when group members work together according to their respective expertise to attain goals. Teamwork complements the skills and commitment to organizational goals with the performance and approach they use to be responsible for their work (Lawasi \& Triatmanto, 2017; Oktapiani, 2010). Teamwork is one of the most important elements in the organization since it depends on individual aspects affecting team performance in achieving the goals set by the organization ((Abdullah et al., 2015). Teamwork can improve cooperation and communication within the company as well as departments outside the company. Teamwork usually consists of people who have different skills in achieving goals (Masyithah et al., 2018). Teamwork consists of three important components such as involving more than two employees together to achieve a shared goal, having a clear role in the team, and ensuring that team members understand each other's roles, working together through 
collaboration to achieve shared goals set. Teamwork can produce products, provide services, coordinate projects, and offer advice in decision-making. According to Robbins \& Judge (2015), teams are divided into four types. They are the problem-solving team to discuss ways to improve the quality of the work environment, self-managed work team with supervisors to make schedules and take action to deal directly with consumers, cross-functional teams containing employees from the same hierarchy but different work areas working to complete a task and virtual teams that use technology to improve the performance of their members.

The findings show that in organizations with teamwork, employees will have more commitment to their organization (Ghorbanhosseini, 2013). According to Hanaysha (2016), the indicator in measuring teamwork is the joint responsibility to complete the work by giving responsibility; good cooperation can be created because each employee will share knowledge to complete the job correctly. Contributing to each other refers to the contribution of energy and thoughts to create cooperation. Maximum deployment of capabilities by mobilizing the abilities of each team member to the maximum, cooperation will be stronger and of higher quality.

\section{Employee training}

Recruiting and selecting employees who are considered to have potential does not guarantee their ability to work viably. To make employees know what they are doing, management must orient and train them. Training is the key to organizational strategy to build a sustainable competitive advantage and survival in the organization. Employee orientation is to provide background information to perform their jobs satisfactorily and provide information about company regulations. Orientation fulfills four main things. It makes new employees feel accepted and comfortable, new employees know the policies and procedures, and new employees can go through the process of getting used to the way the company acts (Dessler, 2015). In general, training refers to the efforts planned by an organization to facilitate the learning of employees about job-related competencies. These competencies are in the form of knowledge, skills, or behaviors that encourage successful job performance (Raymond, 2011).

Employee training is a process to teach new employees or existing employees to provide and add the basic skills they need to do their jobs. Training can involve old employees teaching their work to new employees or conduct seminars Dessler (2015). Newman et al., (2011) revealed that training is an activity to improve one's workability in relation to organizational activities that can assist employees in understanding knowledge and its application to improve work performance so that commitment to the organization will be formed.

Dessler (2015) mentions five techniques in employee training. They are (1) on-the-job training that employees learn a job as well as employ it, (2) internship training that is a combination 
54 Riyadi, R. P. \& Auliya, Z. F., The Role of Employee Empowerment, Teamwork, and...

of formal learning and long-term on-the-job training and is usually a structured process and is under the supervision of an expert worker, (3) job instruction training which is a recording each of the basic job duties to provide training for employees, (4) programmed learning that is a systematic method for teaching job skills, (5) hands-on training with direct practice. According to Hanaysha (2016), indicators in measuring employee training are that employees have learning opportunities to meet changing workplace needs, the material provided in training is in accordance with job needs, the training provided can improve the ability of employees to complete work, and employees feel satisfied with the holding in-company training.

\section{Hypothesis Development}

\section{Employee Empowerment and Organizational Commitment}

Empowerment is an effort to give autonomy, supervisor trust, and creativity encouragement to complete their duties as best as possible (Pratama, et al, 2015). Empowerment is a process that provides opportunities for workers to set their own work-related goals, make decisions, and solve problems within their own scope of responsibility and authority (Hutagaol, 2014). Research conducted by Hanaysha (2016), Mahiri (2017), Hutagaol (2014), Maulina et al., (2017), Ismail et al., (2011), Kuo et al., (2010), Setiawan \& Piartrini (2018) shows that employee empowerment has a significant influence on organizational commitment. This shows that if the company provides sufficient trust and opportunities for employees to develop their creativity for decision-making at work, it will make employees committed to the organization.

$\mathrm{H}_{1}$ : Employee empowerment influences organizational commitment

\section{The Influence of Teamwork on Organizational Commitment}

Teams are two or more people who voluntarily work together to achieve certain predetermined goals. Teamwork is an activity when group members work together according to their respective expertise to achieve goals (Oktapiani, 2010). A team is a unit consisting of two or more people who interact and coordinate about a job and efforts to achieve certain goals (Lawasi \& Triatmanto, 2017). Researches conducted by Hanaysha (2016), Zincirkiran et al., (2015), Musriha (2013) dan Ghorbanhosseini (2013) show that teamwork has a significant influence on organizational commitment. This shows that the higher the teamwork in solving a problem, the higher the commitment to the organization.

$\mathrm{H}_{2}$ : Teamwork influences organizational commitment

\section{The Influence of Employee Training on Organizational Commitment}

To make employees know what they are doing, management must orient and train them. Training is the key to organizational strategy to build a sustainable competitive advantage and survival in the organization ((Hanaysha dan Putri, 2015). Employee training is a process to teach 
new employees or existing employees to add and provide the basic skills they need to do their jobs. Training can involve old employees teaching their work to new employees or conduct seminars (Dessler, 2015). Researches conducted by Dhar (2015), Hanaysha (2016), Adisaksana et al., (2015), dan Ajibade \& Ayinla (2014) show that employee training has a significant influence on organizational commitment. If the company increases the frequency of training for employees, it will increase employee commitment to the organization.

$\mathrm{H}_{3}$ : Employee training influences organizational commitment

\section{METHOD}

\section{Population, Sample, and Sampling Technique}

The population of this study was employees at the Department of Public Works in Banyumas Regency. They worked for bridges and roads maintenance. The samples is a subset of the population consisting of several members of the population. This subset was taken because in many cases it is impossible to take all members of the population for our study. Therefore, sampling is a form of representative population. The sample is part of the number and characteristics possessed by the population on the condition that the samples taken from the population must be truly representative (Sugiyono, 2014). The sample in this study were employees of the Department of Public Works in Banyumas Regency. The characteristics of the sample taken are employees who have received empowerment, employees who work together with teams, and employees who have received training. The number of samples was 80 respondents. They were taken using purposive sampling by setting certain considerations or criteria that must be met by the samples used in this study (Sugiyono, 2014). The considerations for determining the sample are employees who have a minimum length of work of one year so that their organizational commitment can be evaluated and employees have felt enough empowerment, teamwork, and training in the company.

\section{Data collection technique}

Data collection can be done with various settings, sources, and ways. In terms of the method employed, data collection techniques can be done through the interview, questionnaire, observation, and a combination of the three (Sugiyono, 2014). The data collection technique used in this study was a questionnaire. The questionnaire is a data collection technique where respondents fill in questions or statements completely and return them to the researcher (Sugiyono, 2014). The scoring in this questionnaire uses the agree-disagree scale. This case used a 7-point scale. Respondents were asked to choose alternative answers ranging from a scale of 1 (strongly disagree) to a scale of 7 (strongly agree). The agree-disagree scale is another form of a 
56 Riyadi, R. P. \& Auliya, Z. F., The Role of Employee Empowerment, Teamwork, and...

bipolar adjective by developing statements that produce agree-disagree answers in various ranges of values (Ferdinand, 2014). .

\section{Operational Definition of the Variables}

Empowerment is an effort to give autonomy, supervisor trust, and creativity encouragement in order to complete their duties as best they can (Pratama et al, 2015). According to Hanaysha (2016), indicators in measuring employee empowerment are (1) having confidence in the ability and skills to do the job, (2) having the authority and trust from the manager to make the decisions needed to do a good job, and (3) having sufficient opportunities for freedom in doing work. Teamwork can improve cooperation and communication within the company as well as among departments outside the company. Usually, teamwork consists of people who have different expertise to strengthen in achieving company goals (Masyithah et al., 2018). According to Hanaysha (2016), there are three indicators of teamwork, namely (1) the responsibility to jointly complete the work by giving responsibility to create good cooperation since the employee will share knowledge to complete the work, (2) contribute to each other by contributing energy and thoughts to create cooperation, and (3) deploy maximum capabilities of each team member and thereby cooperation will be stronger and of higher quality. Hanaysha (2016) added that indicators in measuring employee training are that employees have learning opportunities to meet changing workplace needs, training materials are in accordance with the job, the training provided is appropriate to meet the needs of abilities on the job, employee satisfaction by holding training within the organization. In addition, Hanaysha (2016) and Wulandari (2020) stated that organizational commitment can be measured using four indicators that are (1) a strong desire to remain as a member, employees are proud to work in the company, and consider the company a good place to work, (2) the desire to try hard at work, the feeling of comfort felt by employees makes employees are motivated to always perform better, and (3) acceptance of organizational values that the values applied and applicable in the organization are in accordance with the values held by employees. Acceptance of organizational goals and their desire to remain in the organization make employees strive hard in carrying out their duties to achieve organizational goals.

\section{RESULTS}

\section{Respondent's Description}

There were 80 respondents to this study. Based on the results of questionnaires distributed directly to employees of the Department of Public Works who have received employee 
empowerment, have collaborated with teams, and have received employee training, the following descriptions of respondents were obtained:

\section{Characteristics by Gender}

The characteristics of respondents based on gender are presented in Table 1.

Table 1. Frequency Distribution of Respondents by Gender

\begin{tabular}{|c|c|c|c|}
\hline & Frequency & Percentage (\%) & Valid percentage (\%) \\
\hline Male & 53 & 66.3 & 66.3 \\
Female & 27 & 33.8 & 33.8 \\
\hline & 80 & 100 & 100 \\
\hline
\end{tabular}

Source: Primary Data Processed in 2021

Table 1 shows that the number of male respondents in this study was $66.3 \%$, while female respondents were $33.8 \%$. This shows that there are more male employees than female employees at the Department of Public Works of Banyumas Regency.

\section{Characteristics by Age}

The respondents based on age were grouped into four. They are those whose age between 20-29 years, between 33-39 years, between 40-49 years, and 50 years and over. The data regarding the age of the respondents are presented in Table 2.

Table 2. Frequency Distribution of Respondents by Age

\begin{tabular}{|c|c|c|c|}
\hline & Frequency & Percentage (\%) & Valid percentage (\%) \\
\hline 20-29 years old & 6 & 7.5 & 7.5 \\
31-40 years old & 13 & 16.3 & 16.3 \\
$41-50$ years old & 31 & 38.8 & 38.8 \\
$>$ 50 years old & 30 & 37.5 & 37.5 \\
\hline & 80 & 100 & 100 \\
\hline
\end{tabular}

Source: Primary Data Processed in 2021

Table 2 shows that employees aged between 20-30 years are 6 people (7.5\%), employees aged between 30-40 years are 13 people (16.3\%), employees aged between 40-50 years are 31 people $(38.8 \%)$, while employees aged 50 years and over are 30 people $(37.5 \%)$. The data shows that the highest number of employees is in the age range of $40-50$ years with a percentage of $38.8 \%$ or as many as 31 people, while employees aged 20-30 years have the least number with a percentage of $7.5 \%$ or as many as 6 people. Based on the results of these data, the employees of the Department of Public Works in Banyumas Regency were dominated by employees with ages of 40-50 years.

\section{Characteristics Based on Level of Education}

Respondent's identities based on education level were grouped into 3 groups. They are Senior/Vocational High School, Diploma, and Bachelor's Degree. The data regarding the education level of the respondents are presented in Table 3. 
58 Riyadi, R. P. \& Auliya, Z. F., The Role of Employee Empowerment, Teamwork, and...

Table 3. Frequency Distribution of Respondents by Level of Education

\begin{tabular}{|c|c|c|c|}
\hline & Frequency & $\begin{array}{c}\text { Percentage } \\
\mathbf{( \% )}\end{array}$ & $\begin{array}{c}\text { Valid percentage } \\
\mathbf{( \% )}\end{array}$ \\
\hline Senior/Vocational High School & 17 & 21.3 & 21.3 \\
Diploma & 2 & 2.5 & 2.5 \\
Bachelor's/Master's Degree & 61 & 76.3 & 76.3 \\
\hline & 80 & 100.0 & 100.0 \\
\hline
\end{tabular}

Source: Primary Data Processed in 2021

Table 3 shows that the number of employees who graduated from Senior/Vocational High School in this study was $21.3 \%$ or 17 people, Diploma was $2.5 \%$ or 2 people, and Bachelor's Degree was $76.3 \%$ or 61 people. Thus, it can be concluded that the employees at the Department of Public Works in Banyumas Regency are mostly from Bachelor's/Master's Degree.

\section{Validity test and Cronbach Alpha}

A validity test is used to measure the validity of a questionnaire. The questionnaire is said to be valid if the questions can reveal something that will be measured (Ghozali, 2011). Whether or not the questionnaire is valid can be obtained if the Corrected Item-Total Correlation $/ \mathrm{r}_{\text {count }}>\mathrm{r}_{\text {table }}$ at a significance of 0.05 with a 2 -tailed test and number of data $(\mathrm{n})=80, \mathrm{df}=\mathrm{n}-2$, then $\mathrm{r}_{\text {table }}$ is 0.2172. The results of the validity test in this study can be seen in Table 4 .

Table 4. Validity and Reliability Test

\begin{tabular}{|l|c|c|}
\hline Variables & Validity Test & Reliability Test \\
\hline Employee Empowerment & .536 & \\
EE1 & .628 & .793 \\
EE2 & .690 & \\
EE3 & .561 & \\
EE4 & & \\
\hline Teamwork & .641 & .850 \\
TW1 & .692 & \\
TW2 & .728 & \\
TW3 & .615 & \\
TW4 & .644 & .841 \\
TW5 & .701 & \\
\hline Employee Training & .718 & \\
ET1 & .676 & \\
ET2 & .627 & \\
ET3 & & \\
ET4 & .620 & \\
\hline Organizational Commitment & .594 & \\
OC1 & .666 & \\
OC2 & .621 & \\
OC3 & .658 & \\
OC4 & & \\
OC5 & & \\
\hline
\end{tabular}


A reliability test is a tool to measure the questionnaire which is an indicator of the variables. A questionnaire can be said to be reliable if the answers from respondents are consistent from time to time (Ghozali, 2013). To measure reliability, Cronbach Alpha $(\alpha)$ can be used. The variable is said to be reliable if the Cronbach Alpha value is $>0.70$ (Ghozali, 2011).

\section{Classical Assumption Test}

The classical assumption test is used to detect whether or not there is a deviation from the classical assumption or the multiple regression equation used. This test consists of the normality test, multicollinearity test, and heteroscedasticity test. Based on the results of the normality test on the residual value of the regression equation in the One-Sample Kolmogorov-Smirnov Test table, the Asymp. Sig. (2-tailed) of 0.200, the value is greater than 0.05. Thus, it can be concluded that the data is normally distributed or it can be said that the regression model is feasible to use because it meets the assumption of normality. Based on the value of tolerance more than 0.10 and all VIF values less than 10. It can be concluded that there is no multicollinearity between independent variables in the regression model. Based on the significance value for the Independent variable, it shows a value above 0.05. Based on these values, it can be concluded that there is no heteroscedasticity in the regression model.

\section{F Test}

Based on the results of the model accuracy test, it can be seen that the calculated $F_{\text {count }}$ is 561.601, while the $\mathrm{F}_{\text {table }}$ is at a significance level of $5 \%$ and the degree of freedom (df1) is $\mathrm{k}=4$, while df $2=\mathrm{n}-(\mathrm{k}-1)=80-(4-1)=77$. If the test is performed using a value of $\mathrm{a}=5 \%$, then the value of $F_{\text {table }}$ is 2.49. So, the $F_{\text {count }}>F_{\text {table }}(561.601>2.49)$. Thus, $H_{0}$ is rejected and $H_{1}$ is accepted. While the value of sig. $0.000<0.05$ (Alpha). Thus, it can be declared significant. It can be concluded from the $\mathrm{F}$ test that the Independent variables of Employee Empowerment (X1), Teamwork (X2), and Employee Training (X3) simultaneously influence Organizational Commitment $(\mathrm{Y})$ Department of Public Works in Banyumas Regency.

\section{Coefficient of Determination Test $\left(R^{2}\right)$}

Based on the results of the Adjusted $\mathrm{R}^{2}$ test, it shows a value of 0.945 or $94.5 \%$. This means that the relationship between the independent variable and the dependent variable is $94.5 \%$. It can be concluded that the variables of Employee Empowerment, Teamwork, and Employee Training have a joint influence of $94.5 \%$ on Organizational Commitment, while the rest is influenced by other variables not discussed in this study.

\section{DISCUSSION}

This study used multiple regression analysis using SPSS 23.0 to explain the influence of several independent variables on the dependent variable. Multiple regression test results can be 
seen in Table 5.

Table 5. Regression Test

\begin{tabular}{|l|r|r|r|r|}
\hline Description & B & \multicolumn{1}{c|}{ t } & \multicolumn{1}{c|}{ Sig. } & Conclusion \\
\hline Employee Empowerment $\rightarrow$ Organizational & -.169 & -2.717 & .008 & Accepted \\
Commitment & .730 & 15.535 & .000 & Accepted \\
Teamwork $\rightarrow$ Organizational Commitment & .000 & Accepted \\
Employee Training $\rightarrow$ Organizational & .462 & 6.745 & .000 \\
Commitment
\end{tabular}

First, based on the calculation, the significance value of the variable of Employee Empowerment (X1) is 0.008. This shows that the employee empowerment variable has a significance value less than 0.05 . Hence, $\mathrm{H}_{0}$ is rejected and $\mathrm{H}_{1}$ is accepted. Therefore, it can be concluded that Employee Empowerment (X1) has a significant influence on Organizational Commitment $(Y)$. Second, the significance value of the variable of Teamwork (X2) is 0.000 . This shows that the variable of Teamwork has a significance value less than 0.05 . Thus, $\mathrm{H}_{0}$ is rejected and $\mathrm{H}_{1}$ is accepted. Based on this analysis, it can be concluded that Teamwork (X2) has a significant influence on Organizational Commitment $(\mathrm{Y})$. Third, the significance value of the variable of Employee Training (X3) is 0.000 . This shows that the variable of employee training has a significance value less than 0.05 . Thus, $\mathrm{H}_{0}$ is rejected and $\mathrm{H}_{1}$ is accepted. Based on this analysis, it can be concluded that Employee Training (X3) has a significant influence on Organizational Commitment $(\mathrm{Y})$.

The results of this study are in line with research conducted by Hanaysha (2016), Hutagaol (2014), Ismail et al., (2011), Setiawan \& Piartrini (2018) showing that employee empowerment has a significant influence on organizational commitment. This shows that if the company gives trust and opportunities for employees to develop their creativity for decision-making at work, it will make employees committed to the organization. The results of this study are in line with previous research conducted by Hanaysha (2016), Zincirkiran et al., (2015), and Ghorbanhosseini (2013) that teamwork has a significant influence on organizational commitment. This shows that the higher the teamwork in solving a problem, the higher the commitment to the organization. The results of this study are in line with research conducted by Dhar (2015), Hanaysha (2016), Adisaksana et al., (2015), dan Ajibade \& Ayinla (2014) that employee training has a significant influence on organizational commitment. If the company increases the frequency of training for employees, it will increase employee commitment to the organization.

\section{CONCLUSIONS, LIMITATIONS, AND SUGGESTIONS}

The results of this study show that all variables have a significant influence on organizational commitment. The best result in this research is the role of teamwork in increasing 
organizational commitment. Organizations need to improve coordination so teams become more solid, encourage all employees to be responsible, and improve teamwork by working hand in hand and encouraging close relationships among members of the team. Organizations also need to conduct regular employee training be it outside or in-office training. The results show that the influence of employee empowerment on organizational commitment is negative and significant. This means that increasing empowerment actually reduces organizational commitment. Thus, what the organization emphasizes more is not increasing empowerment but more prioritizing activities that build human relations between employees such as activities that encourage solidity and close relationships such as outbound, joint sports, strengthening the capacity building. Hence, employees have good relationships at work as indicated by increased teamwork and increased commitment to the organization. In the future, this research can be carried out in various organization, not only in public organizations.

\section{REFERENCES}

Abdullah, A. G. K. bin, Almadhoun, T. Z., \& Ling, Y.-L. (2015). Organizational Empowerment and Commitment: The Mediating Effect of Psychological Empowerment. Asian Journal of Social Sciences, Arts and Humanities, 3(2), 1-7.

Adisaksana, H., Astuti, E. S., \& Musadieq, M. Al. (2015). Pengaruh Pelatihan Kerja dan Insentif Terhadap Kepuasan Kerja dan Dampaknya Terhadap Komitmen Organisasional. Wacana, Jurnal Sosial Dan Humaniora, 18(02), 136-145. https://doi.org/10.21776/ub.wacana.2015.018.02.7

Ajibade, O., \& Ayinla, K. (2014). Investigating the effect of training on employees' commitment: An empirical study of a discount house in Nigeria. Megatrend Revija, 11(3), 7-18. https://doi.org/10.5937/megrev1403007a

Albdour, A. A., \& Altarawneh, I. I. (2014). Employee engagement and organizational commitment: Evidence from Jordan. International Journal of Business, 19(2), 192-212.

Azeem, S. M., \& Akhtar, N. (2014). Job Satisfaction and Organizational Commitment among Public Sector Employees in Saudi Arabia. International Journal of Business and Social Science., 5(7), 127-133.

Azman Ismail, Hasan Al-Banna Mohamed, Ahmad Zaidi Sulaiman, M. H. M. \& M. H. Y. (2011). An Empirical Study of The Relationship Between Transformational Leadership, Empowerment and Organizational Commitment. Business and Economics Research Journal (BERj), Turkey, 2(1), 89-107.

Dessler, G. (2015). Manajer Sumber Daya Manusia (Edisi 14). Salemba Empat.

Dhar, R. L. (2015). Service quality and the training of employees: The mediating role of organizational commitment. Tourism Management, 46, 419-430. https://doi.org/10.1016/j.tourman.2014.08.001 
Ferdinand, A. (2014). Metode Penelitian Manajemen. Pedoman Penelitian untuk Penulisan Skripsi, Tesis dan Disertasi Ilmu Manajemen (5th ed.). Undip Press.

Ghorbanhosseini, M. (2013). The effect of organizational culture, teamwork and organizational development on organizational commitment: The mediating role of human capital. Tehnicki Vjesnik, 20(6), 1019-1025.

Ghozali, I. (2011). Aplikasi Analisis Multivariat dengan Program SPSS 20. Badan Penerbit Universitas Diponegoro.

Hanaysha, J. (2016). Examining the Effects of Employee Empowerment, Teamwork, and Employee Training on Organizational Commitment. Procedia - Social and Behavioral Sciences, 229, 298-306. https://doi.org/10.1016/j.sbspro.2016.07.140

Hutagaol, I. M. (2014). Employee Empowerment on Organizational Commitment in Bank Indonesia Representative in North Sulawesi. Jurnal Riset Ekonomi, Manajemen, Bisnis Dan Akuntansi, 2(3), 921-930.

Idayanti Nursyamsi. (2012). Pengaruh kepemimpinan, pemberdayaan dan stress kerja terhadap komitmen organisasional serta dampaknya terhadap kinerja dosen. Conference In Business, Accounting, And Management, 405-423.

Karim, F., \& Rehman, O. (2012). Impact of Job Satisfaction, Perceived Organizational Justice and Employee Empowerment on Organizational Commitment in Semi-Government Organizations of Pakistan. Journal of Business Studies Quarterly, 3(4), 92-104.

Lawasi, E. S., \& Triatmanto, B. (2017). Pengaruh Komunikasi, Motivasi Dan Kerjasama Tim Terhadap Peningkatan Kinerja Karyawan. Jurnal Manajemen Dan Kewirausahaan, 5(1), 47-57.

Mahiri, E. A. (2017). Pengaruh Pemberdayaan Karyawan Terhadap Komitmen Organisasional Pada Karyawan Perusahaan Daerah Air Minum (PDAM) Kantor Pusat Majalengka. Jurnal Ilmiah Manajemen \& Akuntansi, 4(2), 108-114.

Masyithah, S. M., Adam, M., \& Tabran, M. (2018). Analisis Pengaruh Kompensasi, Kerjasama Tim dan Budaya Organisasi terhadap Kepuasan Kerja serta Dampaknya pada Kinerja Karyawan PT. Bank Muamalat Cabang Banda Aceh. Simen, 9(1), 50-59.

Meyer, J. P., Morin, A. J. S., \& Vandenberghe, C. (2015). Dual commitment to organization and supervisor: Aperson-centered approach. Journal of Vocational Behavior, 88, 56-72. https://doi.org/10.6007/ijarbss/v6-i12/2464

Musriha. (2013). Influence of Teamwork, Environment on Job Satisfaction and Job Performance of the Cigarette Rollers at Clove Cigarette Factories in East Java, Indonesia. Developing Country Studies, 3(2), 32-41.

Newman, A., Thanacoody, R., \& Hui, W. (2011). The impact of employee perceptions of training on organizational commitment and turnover intentions: A study of multinationals in the Chinese service sector. International Journal of Human Resource Management, 22(8), 1765-1787. https://doi.org/10.1080/09585192.2011.565667

Oktapiani, M. (2010). Hubungan Antara Lingkungan Kerja Dan Kerjasama Tim Dengan Kepuasan Kerja (Studi Korelasional pada Guru Raudhatul Athfal di Wilayah Duren Sawit Jakarta Timur 
). Jurnal Manajemen Pendidikan, 239-245.

Raymond, N. A. (2011). Manajemen Sumber Daya Manusia Mencapai Keunggulan Bersaing (Edisi 6 Bu). Salemba Empat.

Robbins, S. P., \& Judge, T. A. (2015). Perilaku Organisasi (Edisi 16). Salemba Empat.

Setiawan, I. P. I., \& Piartrini, P. S. (2018). Pengaruh Pemberdayaan Karyawan dan Stres Kerja Terhadap Komitmen Organisasional Karyawan Departemen Housekeeping Pada Villa Ocean Blue. E-Jurnal Manajemen Universitas Udayana, 7(1), 164-191.

Sugiyono. (2014). Metode Penelitian Kuantitatif, Kualitatif, dan R\&DD. Alfabeta.

Wulandari, F. (2020). Manajemen Sumber Daya Manusia (1st ed.). Gerbang Media.

Yusnita, N., \& Fadhil, F. (2015). Pengaruh Pelatihan Karyawan Terhadap Kinerja Karyawan Pada CV Cibalung Happy Land Bogor. JIMFE (Jurnal Ilmiah Manajemen Fakultas Ekonomi), 1(1), 15.

Zincirkiran, M., Emhan, A., \& Fatih Yasar, M. (2015). Analysis of Teamwork, Organizational Commitment and Organizational Performance: A Study of Health Sector in Turkey. Asian Journal of Business and Management, 03(02), 2321-2802. 